Удк 615.322:665.53:582.628.2

\title{
СРАВНИТЕЛЬНЫЙ АНАЛИЗ ЭФИРНОГО МАСЛА РАСТИТЕЛЬНОГО СЫРЬЯ ЛИМОННИКА КИТАЙСКОГО: ЛИСТЬЕВ, ДЕРЕВЯНИСТЫХ СТЕБЛЕЙ, КОРНЕВИЩ С КОРНЯМИ
}

\author{
(C) Ю.А. Морозов ${ }^{1 * *}$, И.Н. Зилфикаров ${ }^{2}$, Е.В. Морозова ${ }^{1}$, А.М. Алиев ${ }^{3}$, Т.А. Ибрагимов ${ }^{4}$ \\ ${ }^{1}$ Северо-Осетинский государственный университет им. К.Л. Хетагурова, \\ ул. Ватутина, 44-46, Владикавказ, 362025 (Россия), \\ e-mail:moroz52@yandex.ru \\ ${ }^{2}$ Всероссийский научно-исследовательский институт лекарственных \\ и ароматических растений, ул. Грина, 7/1, Москва, 117216 (Россия) \\ ${ }^{3}$ Институт фризики им. Х.И. Амирханова Дагестанского научного центра \\ Российской академии наук, ул. Ярагского, 94, Махачкала, 367003 (Россия) \\ ${ }^{4}$ Дагестанский государственный университет, ул. Батырая, 4, Махачкала, \\ 367000 (Россия)
}

\begin{abstract}
В работе приводятся результаты экспериментального исследования компонентного состава образцов эфирных масел, полученных из различного растительного сырья лимонника китайского (Schisandra chinensis (Turcz.) Baill.): ветвей (деревянистых стеблей), корневищ с корнями и листьев. Выделение эфирных масел проводили перегонкой с водяным паром с последующей экстракцией из дистиллята этоксиэтаном. Наибольший выход эфирного масла в пересчете на абсолютно сухое сырье зарегистрирован из корневищ с корнями $-0.99 \%$; выход из листьев и ветвей был примерно одинаков: 0.51 и $0.52 \%$ соответственно. Сравнительный анализ компонентного состава полученных эфирных масел проведен с помощью метода газовой хроматографии / масс-спектрометрии. В эфирном масле листьев обнаружено 29 соединений (идентифицировано 21 соединение; доминирующие компоненты: Циклогексилметиловый эфир сернистой кислоты, (+)-транс-неролидол, $\delta$-кадинен, тридек-(2Е)-ен-1-ол), деревянистых стеблей 80 соединений (идентифицировано 65 соединений; доминирующие компоненты: $\beta$-пинен, Камфен, Борнилацетат, (+)-транс-неролидол, $n$ цимен, Тридекан-2-он, $\delta$-кадинен), корневищ с корнями 78 соединений (идентифицировано 60 соединений; доминирующие компоненты: $\delta$-кадинен, Борнилацетат, $\beta$-пинен, Камфен, Неролидол-(Е), Тридекан-2-он, $\gamma$-кадинен, Борнеол). Для каждого образца исследуемых эфирных масел установлены селективность и вещества-маркеры.

Ключевые слова: лимонник китайский, эфирное масло, газовая хроматография / масс-спектрометрия.
\end{abstract}

\section{Введение}

Морозов Юрий Алексеевич - кандидат

фармацевтических наук, доцент, доцент кафедры

фармации, e-mail: moroz52@yandex.ru

Зилфикаров Ифрат Назимович - доктор

фармацевтических наук, профессор РАН, главный

научный сотрудник отдела фитохимии,

e-mail: dagfarm@mail.ru

Морозова Елизавета Владимировна - кандидат фармацевтических наук, доцент, доцент кафедры фармации, e-mail: maychelo@mail.ru

Алиев Аслан Мурадалиевич - старший научный сотрудник лаборатории термодинамики жидкостей и критических явлений, e-mail: aslan4848@yahoo.com Ибрагимов Тимур Алгасанович - кандидат фармацевтических наук, доцент кафедры аналитической и фармацевтической химии, e-mail: aloefarm@mail.ru
Лимонник китайский (Schisandra chinensis (Turcz.) Baill.) семейства лимонниковых (Schisandraceae Blume) - многолетняя деревянистая вьющаяся листопадная лиана [1].

Плоды и семена лимонника издавна применяются в официальной медицине в качестве «классических» адаптогенов, повышающих физическую активность, выносливость и работоспособность. В народной медицине применяют все части растения: подземные (корневища с корнями и их кора) и надземные (плоды, семена, листья, одревесневшие стебли) [2-4].

\footnotetext{
*Данная статья имеет электронный дополнительный материал (приложение), который доступен читателям на сайте журнала. DOI: 10.14258/jcprm.2019013912s.

** Автор, с которым следует вести переписку.
} 
Химический состав различного вида сырья лимонника китайского представлен разнообразными группами биологически активных веществ. Основной фармакологический эффект растения связывают с высоким содержанием дибензоциклооктановых лигнанов, которые обнаружены как в надземных, так и в подземных его органах. Наряду с лигнанами во всех органах лимонника китайского содержится эфирное масло $(Э \mathrm{M})[5,6]$.

В литературе встречается небольшое количество работ, посвященных изучению химического анализа ЭМ различного вида растительного сырья лимонника китайского.

Так, в работе [7] приводятся сведения о содержании в стеблях лимонника (только мужские экземпляры) свыше 2\% ЭМ, из коры стеблей получено до 3.14\%, в семенах ЭМ содержится около 1.6-2\%. Для каждого из масел определены соответствующие константы. Полученное из семян ЭМ бесцветное, при хранении на воздухе желтеет, растворимость в этиловом спирте составляет $1: 2.8$, в сильном разбавлении обладает тонким ароматом, напоминающим запах лимонной корки.

На основе экспериментальных данных, полученных в результате проделанных химических реакций, Ф.Т. Запатылько сделан вывод о том, что ЭМ из семян лимонника не содержит альдегидов, кетонов и ароматических углеводородов; для лучшей сохранности (в силу легкой окисляемости) целесообразней его применять в смеси с жирным маслом [8].

Существуют и более ранние исследования (Ю.В. Бранке, И.И. Парышев, 1937 г.; П.А. Сенов, 1938 г.), согласно которым в ЭМ полученном из листьев лимонника содержится до 18-20\% альдегидов и кетонов, в ЭМ коры до 30\% сесквитерпеновых соединений.

И.В. Кротовой и А.А. Ефремовым методом дистилляции с водяным паром из высушенных плодов лимонника китайского получено ЭМ, обладающее приятным запахом и своеобразным, горьким вкусом. Определены физические константы; выход продукта составил 1.6\%. Хроматографическим способом установлен химический состав ЭМ: сесквитерпеновых углеводородов более чем 60\% вес. (иланген 5.9\% вес., хамигрен 19.5\% вес., сесквикарен 10.9\% вес., камигреналь 24.5\% вес.), алифатические терпены в количестве $4.0 \%$ вес., моноциклических терпенов около $13.5 \%$ вес., бициклических терпенов ряда пинана и ряда камфана более $3 \%$ вес. и $4.6 \%$ вес. соответственно [9, 10$]$.

Сотрудниками Дальневосточного научно-исследовательского института лесного хозяйства с помощью всесторонних экспериментальных исследований получены и проанализированы ЭМ и флорентинные воды из лиан, семян и отходов производства (жома) сока лимонника китайского. Выход ЭМ в расчете на абсолютно сухую массу составил для лиан $-0.72-0.98 \%$, для семян $-0.77-1.07 \%$ и для жома $-0.65-1.01 \%$. Отмечено, что во всех исследуемых образцах ЭМ присутствует схизандрин $[1,11]$.

Количественное содержание ЭМ в листьях лимонника, заготовленных в Воронежской области, составило $0.98 \%$ [12].

В работе [13] приводятся результаты изучения химического состава эфирного масла из семян лимонника китайского хромато-спектрометрическим методом; идентифицированы соединения, относящиеся к разным классам: спиртам, кислотам, сахарам, кетонам, антраценпроизводным, терпенам, эфирам.

Китайскими учеными из плодов лимонника ЭМ получено с использованием двух способов: «Неadspace» твердофазной микроэкстракции (HS-SPME) и дистилляцией с паром. Химический состав исследуемых образцов проанализирован с помощью газовой хромато-масс-спектрометрии: для ЭМ, полученного методом HS-SPME, идентифицировано 33 летучих соединения, для метода дистилляции с паром - 35 [14].

Чаще всего ЭМ применяются в производстве фармацевтических продуктов в качестве вспомогательных веществ (корригенты вкуса и запаха, консерванты), реже - в качестве фармацевтических субстанций, хотя и обладают разнообразными фармакологическими свойствами [15].

Согласно данным литературы, ЭМ лимонника обладает адаптогенным, общестимулирующим, психостимулирующим, жаропонижающим, противовоспалительным, регенерирующим, антисептическим, бактерицидным и фунгицидным действием. Среди возможных методов применения известны: ароматические лампы и кулоны, ванные и массажные процедуры, ингаляции [16, 17].

Эфирное масло, выделенное из семян лимонника китайского J.W. Jeong с соавторами, ингибирует фактор некроза опухолей в клетках гладких мышц аорты человека, что демонстрирует о его потенциальной антиатеросклеротической активности [18].

Других современных данных, касающихся методов получения и сравнительных исследований химического состава эфирного масла различного растительного сырья лимонника, в доступной нам литературе не встречено. 
Поэтому основной целью данной работы является выделение эфирных масел и изучение их химического состава у различного растительного сырья лимонника китайского: листьев, деревянистых стеблей (ветвей) и корневищ с корнями.

\section{Экспериментальная часть}

Изученные нами образцы эфирного масла были получены из надземной (листья и одревесневшие стебли) и подземной части (корневища с корнями) Schisandra chinensis (Turcz.) Baill. Высушенное до остаточной влажности растительное сырье (табл. 1) измельчалось вручную до размера частиц, проходящих сквозь сито с диаметром 3-5 мм.

Выделение ЭМ от каждого образца осуществляли перегонкой с водяным паром при атмосферном давлении на собранной для этого лабораторной установке в течение 2 ч с последующей жидкость-жидкостной экстракцией дистиллята диэтиловым эфиром. Эфирные извлечения упаривали под вакуумом при температуре не выше $35^{\circ} \mathrm{C}$ до маслянистого остатка, который затем взвешивали и растворяли в гексане.

Эфирное масло исследовали методом хромато-масс-спектрометрии на приборе Shimadzu GCMSQP2010plus с колонкой Supelco SLBTM-5ms $(30 \mathrm{~m} \times 0.25 \mathrm{~mm} \times 0.25 \mu \mathrm{m})$ в режиме «split». В качестве газаносителя использовался гелий чистотой 99.9999\% в режиме стабилизации потока скоростью 1 мл/мин. Температура колонки поднималась от $60^{\circ} \mathrm{C}$ (выдержка 4 мин) до $150{ }^{\circ} \mathrm{C}$ со скоростью $10{ }^{\circ} \mathrm{C} /$ мин, далее до $250{ }^{\circ} \mathrm{C}$ со скоростью $5^{\circ} \mathrm{C} /$ мин. Температура инжектора, интерфейса и детектора $-250{ }^{\circ} \mathrm{C}$. Ионизация электронным ударом с энергией электронов - 70 эВ. Ток эмиссии катода - 60 мкА, диапазон регистрируемых ионов с m/z 45-500. Объем пробы - 1 мкл, деление потока - $1: 36$.

Процентный состав ЭМ вычисляли по площадям газохроматографических пиков без использования корректирующих коэффициентов. Качественный анализ основан на сравнении времен удерживания и полных масс-спектров с соответствующими данными компонентов эталонных масел и чистых соединений, если они имелись; идентификация компонентов ЭМ проводилась по линейным индексам удерживания при совпадении масс-спектров с вероятностью 95\% и выше; использовались лицензионные библиотеки массспектров NIST08 и FFNSC [20-22].

Таблица 1. Характеристика исследованных образцов растительного сырья лимонника китайского

\begin{tabular}{|c|c|c|c|}
\hline Образец & География, экология, время сбора сырья и дата получения эфирного масла & $\begin{array}{c}\text { Влажность, } \\
\text { \% [19] }\end{array}$ & $\begin{array}{c}\text { Выход } \\
\text { масла, \%* }\end{array}$ \\
\hline \multicolumn{4}{|c|}{ Schisandra chinensis (Turcz.) Baill. } \\
\hline Листья & $\begin{array}{l}\text { Брянская область, Унечский район, д. Пески, ООО «ССХП «Женьшень»»», } \\
\text { промышленные плантации, в защищенных укрытиях от попадания прямого } \\
\text { солнечного света, весна } 2014 \text { г. (фаза цветения), 10.04.2015 г. }\end{array}$ & 4.40 & 0.51 \\
\hline $\begin{array}{l}\text { Деревянистые } \\
\text { стебли }\end{array}$ & $\begin{array}{l}\text { Брянская область, Унечский район, д. Пески, ООО «ССХП «Женьшень»»», } \\
\text { промышленные плантации, в защищенных укрытиях от попадания прямого } \\
\text { солнечного света, весна } 2014 \text { г. (фаза сокодвижения), } 11.04 .2015 \text { г. }\end{array}$ & 5.06 & 0.52 \\
\hline $\begin{array}{l}\text { Корневища } \\
\text { с корнями }\end{array}$ & $\begin{array}{l}\text { Брянская область, Унечский район, д. Пески, ООО «ССХП «Женьшень»»", } \\
\text { промышленные плантации, в защищенных укрытиях от попадания прямого } \\
\text { солнечного света, весна } 2014 \text { г. (фаза сокодвижения), 12.04.2015 г. }\end{array}$ & 4.98 & 0.99 \\
\hline
\end{tabular}

Примечание: * в расчете на воздушно-сухое сырье.

\section{Обсуждение результатов}

Полученные в ходе эксперимента образцы ЭМ представляют собой маслянистые жидкости от светло-желтого (из ветвей и корневищ с корнями) или желтого с зеленоватым, или коричневатым оттенком (из листьев) цвета с выраженным характерным для лимонника запахом; в ЭМ из листьев проявлялся также терпкий травяной запах. Вкус жгучий, пряный.

Согласно данным, приведенным в таблице 1, наибольший выход ЭМ отмечен из корневищ с корнями, из надземных органов выход составил практически одинаковые значения.

В эфирном масле одревесневших стеблей обнаружено 80 соединений, корневищ с корнями - 78, листьев -29.

Основные результаты исследования компонентного состава образцов ЭМ, полученных из листьев, ветвей и корневищ $\mathrm{c}$ корнями лимонника китайского методом газовой хроматографии с масс- 
спектрометрической детекцией, приведены в таблице 2. Общий вид хроматограмм показан на рисунке в электронном приложении.

Представленные в таблице 2 данные свидетельствуют о том, что качественный и количественный состав ЭМ различного вида растительного сырья лимонника китайского имеет как сходства, так и различия. По компонентному составу монотерпенов (ациклических, моноциклических, бициклических, трициклических) образцы ЭМ, полученного из ветвей и корневищ с корнями, практически идентичны друг другу; содержание монотерпенов в ЭМ ветвей в 2 раза превосходит их содержание в ЭМ корневищ с корнями. В образцах ЭМ, полученного из листьев, монотерпены отсутствуют полностью.

По содержанию меньше всего сесквитерпенов обнаружено в ЭМ ветвей, при этом в его составе встречаются вещества, которые не были найдены в образцах ЭМ корневищ с корнями и листьев: $\beta$ фарнезен (алифатический сесквитерпен); (+)-сативен, циклизосативен, гвайя-6,9-диен, гвайя-1(10),11-диен (бициклические сесквитерпены); $\alpha$-копаен, лонгифолен (трициклические сесквитерпены). Наряду с алифатическими в ЭМ листьев также отсутствуют и трициклические сесквитерпены.

Таблица 2. Компонентный состав эфирных масел (\% компонента от суммы) различного растительного сырья лимонника китайского

\begin{tabular}{|c|c|c|c|c|}
\hline \multirow{2}{*}{ Наименование компонента } & \multirow{2}{*}{$\begin{array}{c}\text { Индекс } \\
\text { удерживания }\end{array}$} & \multicolumn{3}{|c|}{$\begin{array}{c}\text { Содержание компонентов } \\
\text { от цельного эфирного масла, \% }\end{array}$} \\
\hline & & ветвей & $\begin{array}{c}\text { корневищ с } \\
\text { корнями }\end{array}$ & листьев \\
\hline 1 & 2 & 3 & 4 & 5 \\
\hline Трициклен & 923 & 0.29 & 0.19 & - \\
\hline$\alpha$-туйен & 927 & 0.41 & 0.19 & - \\
\hline$\alpha$-пинен & 933 & 2.94 & 1.34 & - \\
\hline Камфен & 953 & 4.28 & 3.15 & - \\
\hline Сабинен & 972 & 2.15 & 0.77 & - \\
\hline$\beta$-пинен & 978 & 11.91 & 6.41 & - \\
\hline 6-метил-6-гептен-2-он & 986 & 0.43 & 1.55 & - \\
\hline Мирцен & 991 & 1.36 & 0.60 & - \\
\hline$\alpha$-фелландрен & 1007 & 0.39 & 0.07 & - \\
\hline$\alpha$-терпинен & 1018 & 0.75 & 0.25 & - \\
\hline$n$-цимен & 1025 & 3.03 & 1.41 & - \\
\hline Лимонен & 1030 & 1.77 & 0.82 & - \\
\hline Цинеол & 1032 & 1.55 & 1.45 & - \\
\hline$\gamma$-терпинен & 1058 & 1.97 & 0.42 & - \\
\hline Терпинолен & 1086 & 0.50 & 0.15 & - \\
\hline Лавандовый кетон метила & 1089 & 0.10 & 0.12 & - \\
\hline Линалоол & 1101 & 0.62 & 0.62 & 0.66 \\
\hline Мент-2-ен-1-ол(цис-, пара) & 1109 & 0.40 & 0.12 & - \\
\hline Фенетиловый спирт & 1113 & - & - & 1.44 \\
\hline$n$-ментон & 1148 & - & 0.18 & - \\
\hline$\beta$-цитронеллаль & 1152 & 0.66 & 0.37 & - \\
\hline Борнеол & 1173 & 0.81 & 3.10 & - \\
\hline Терпинен-4-ол & 1180 & 2.72 & 1.39 & - \\
\hline Ментол & 1184 & - & 1.35 & 0.44 \\
\hline$n$-цимен-8-ол & 1189 & 0.18 & 0.22 & - \\
\hline$\alpha$-терпинеол & 1195 & 1.02 & 0.63 & - \\
\hline Цитронеллол & 1232 & 0.26 & 0.13 & - \\
\hline Тимол метиловый эфир & 1239 & 1.83 & 0.98 & - \\
\hline Пулегон & 1241 & 0.09 & 0.19 & - \\
\hline 2-метилдодекан & 1249 & - & - & 0.69 \\
\hline Линалилацетат & 1250 & 0.10 & 0.08 & - \\
\hline Борнилацетат & 1277 & 9.94 & 8.27 & - \\
\hline 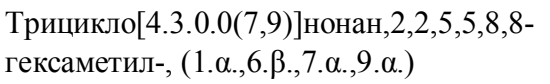 & 1287 & - & - & 3.68 \\
\hline Карвакрол & 1300 & 0.25 & 0.17 & - \\
\hline Цитриодиол & 1320 & 0.16 & 0.13 & - \\
\hline$\alpha$-терпинилацетат & 1349 & 0.82 & 0.53 & - \\
\hline
\end{tabular}


Окончание таблищь 2

\begin{tabular}{|c|c|c|c|c|}
\hline 1 & 2 & 3 & 4 & 5 \\
\hline$\alpha$-кубебен & 1350 & 0.14 & 0.32 & - \\
\hline Циклоизосативен & 1367 & 0.08 & - & - \\
\hline$\alpha$-копаен & 1375 & 0.35 & - & - \\
\hline$\beta$-элемен & 1390 & 1.99 & 0.80 & - \\
\hline Лонгифолен & 1412 & 0.54 & - & - \\
\hline$\beta$-маалиен & 1415 & - & 0.11 & - \\
\hline Дигидроактинидиолид & 1426 & - & - & 1.95 \\
\hline Туйопсен & 1433 & - & 0.48 & - \\
\hline транс-ү-кадинен & 1435 & 0.81 & 0.42 & - \\
\hline 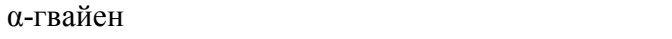 & 1438 & 0.17 & 0.36 & - \\
\hline Гвайя-6,9-диен & 1444 & 0.56 & - & - \\
\hline$\beta$-фарнезен & 1452 & 0.59 & - & - \\
\hline Кадина-3,5-диен & 1452 & 0.28 & 0.61 & - \\
\hline Кадина-1(6),4-диен & 1472 & 0.19 & 1.00 & 0.52 \\
\hline$(+)$-сативен & 1476 & 0.29 & - & - \\
\hline Гвайя-1(10),11-диен & 1490 & 0.72 & - & - \\
\hline Тридекан-2-он & 1495 & 3.26 & 3.62 & 4.61 \\
\hline Бициклогермакрен & 1497 & 0.72 & 1.21 & 0.93 \\
\hline цисс- $\alpha$-бисаболен & 1503 & 1.10 & 0.29 & - \\
\hline Хамигрен & 1507 & 1.51 & 0.99 & 1.74 \\
\hline$\beta$-бисаболен & 1508 & 0.46 & 0.56 & 1.76 \\
\hline$\gamma$-кадинен & 1512 & 1.33 & 3.64 & 1.59 \\
\hline$\delta$-кадинен & 1518 & 3.31 & 8.48 & 5.92 \\
\hline транс-каламенен & 1527 & 0.12 & - & 2.1 \\
\hline$\beta$-гимахален & 1528 & 0.24 & 0.25 & - \\
\hline (-)-спатуленол & 1536 & 0.18 & 0.49 & - \\
\hline$\alpha$-калакорен & 1544 & 0.16 & 0.29 & - \\
\hline (+)-купарен & 1556 & 2.28 & 2.19 & 5.43 \\
\hline$\beta$-акорадиен & 1557 & 0.71 & 0.66 & - \\
\hline Неролидол-(Е) & 1561 & - & 7.78 & - \\
\hline 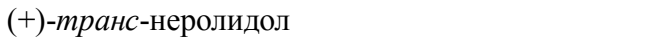 & 1564 & 7.23 & - & 8.63 \\
\hline Тридек-(2Е)-ен-1-ол & 1573 & - & - & 9.47 \\
\hline Спатуленол & 1576 & 0.73 & 1.61 & 1.23 \\
\hline Кадинен-4-ен-10-ол & 1659 & 1.59 & 1.49 & 1.03 \\
\hline Селина-6-ен-4-ол & 1668 & 0.37 & - & - \\
\hline$\alpha$-бисаболол & 1688 & 0.08 & 0.21 & - \\
\hline $\begin{array}{l}\text { 6-изопропенил-4,8а-диметил-1,2,3,5,6,7,8,8a- } \\
\text { октагидронафталин-2-ол }\end{array}$ & 1690 & 0.38 & 0.60 & - \\
\hline Метиловый кетон тридецила & 1697 & 0.29 & 0.96 & - \\
\hline транс-фарнезилацетат & 1834 & - & 0.36 & - \\
\hline 3,5-ди-трет-бутил-4-гидроксибензальдегида & 1856 & 0.10 & 0.08 & 0.97 \\
\hline Циклогексилметиловый эфир сернистой кислоты & 2000 & - & - & 25.03 \\
\hline Обццее содерэсание компонентов & & 86.55 & 77.21 & 79.82 \\
\hline Не идентифицированные вещества & & $13.45^{*}$ & $22.79^{* *}$ & $20.18^{* * *}$ \\
\hline
\end{tabular}

Примечание: *- не идентифицировано 15 веществ; ** - не идентифицировано 18 веществ; *** - не идентифицировано 8 веществ.

Терпеноиды исследуемых ЭМ отличались большим разнообразием. Наличие борнилацетата - основного терпеноида (эфира) определяющего качества ЭМ, выявлено в образцах ЭМ ветвей и корневищ с корнями. Одним из доминирующим спиртовым трепеноидом во всех трех объектах исследования является (+)-транс-неролидол (ЭМ ветвей и листьев) и неролидол-(Е) (ЭМ корневищ с корнями) - более 7\%.

Терпеноидные альдегиды и кетоны присутствуют во всех образцах в незначительных количествах, за исключением кетона тридекана-2-она, содержащегося в ЭМ ветвей, корневищ с корнями и листьев примерно в одинаковых количествах $-3.26,3.62$ и $4.61 \%$ соответственно.

Селективность ЭФ ветвей и корневищ с корнями лимонника китайского составила 10 и 12 соответственно. В ЭМ листьев селективность на $46 \%$ обеспечивает циклогексилметиловый эфир сернистой кислоты (табл. электронное приложение).

Для ЭМ ветвей, корневищ с корнями и листьев лимонника китайского установлены 8,5 и 6 веществмаркеров соответственно. 


\section{Выводы}

1. Методом паровой дистилляции с последующей жидкость-жидкостной экстракцией из различных частей лимонника китайского (деревянистых стеблей, корневищ с корнями, листьев) получены образцы эфирных масел. Наибольший выход ЭМ отмечен из корневищ с корнями (0.99\%), наименьший - из деревянистых стеблей $(0.52 \%)$ и листьев $(0.51 \%)$.

2. Методом газовой хроматографии с масс-спектрометрической детекцией оценен химический состав полученных образцов ЭМ. В ЭМ листьев обнаружено 29 соединений (не идентифицировано 8 веществ), деревянистых стеблей - 80 соединений (не идентифицировано 15 веществ), корневищ с корнями 78 соединений (не идентифицировано 18 веществ).

3. Проведен сравнительный анализ компонентного состава исследуемых ЭМ, позволивший установить для каждого образца доминирующие компоненты, селективность и вещества-маркеры.

Авторы статьи благодарны директору ООО «Специализированное сельскохозяйственное предприятие «Женьшень»», кандидату сельскохозяйственных наук Мешкову Ивану Ивановичу за предоставленное растительное сырье лимонника китайского.

\section{Список литературы}

1. Ошкина Е.В., Колесникова Р.Д., Выводцев Н.В., Тагильцев Ю.Г. Лимонник китайский - дальневосточный эфиронос // Известия ВУЗов. Лесной журнал. 2014. №5. С. 35-41.

2. Мальцева А.А., Тамилина И.А., Недосекова М.А., Тринеева О.В., Сливкин А.И., Чистякова А.С. Изучение лигнанов в листьях лимонника китайского ТСХ // Вестник ВГУ, Серия: Химия. Биология. Фармация. 2015. №1. С. 147-151.

3. Карлина М.В, Косман В.М., Пожарицкая О.Н., Шиков А.Н., Макаров В.Г. Фармакокинетика схизандрола А на крысах при введении масляного экстракта лимонника // Разработка и регистрация лекарственных средств. 2014. №1. C. 34-39.

4. Ториков В.Е., Мешков И.И. Экология, особенности выращивания и элементный состав листьев лимонника китайского (Schisandra chinensis (Turcz.) Ваill.) в Брянской области // Вестник Брянской ГСХА. 2016. №4 (56). C. $50-54$.

5. Косман В.М., Карлина М.В., Пожарицкая О.Н., Шиков А.Н., Макаров В.Г., Воробьева В.В., Лапкина Г.Я. Фармакокинетика лигнанов лимонника китайского // Обзоры по клинической фармакологии и лекарственной терапии. 2015. Т. 13. №4. С. 3-21.

6. Сатдарова Ф.Ш., Куркин В.А. Лигнаны $\mathrm{CO}_{2}$-экстракта лимонника китайского // Химия растительного сырья. 2008. №3. С. 59-63.

7. Супрунов Н.И., Горовой П.Г., Панков Ю.А. Эфирномасличные растения Дальнего Востока. Новосибирск, 1972. $188 \mathrm{c}$.

8. Запатылько Ф.Т. Химическое исследование эфирного масла лимонника // Материалы к изучению женьшеня и лимонника: сборник научных трудов. М.; Л., 1955. Вып. 2. С. 97-99.

9. Кротова И.В., Ефремов А.А. Исследование химического состава плодов лимонника китайского // Химия растительного сырья. 1999. №4. С. 131-133.

10. Кротова И.В., Ефремов А.А. Возможности рационального использования эфиромасличных растений // Химия растительного сырья. 2002. №3. С. 29-33.

11. Колесникова Р.Д., Тагильцев Ю.Г. Эфирные масла лимонника китайского (Schisandra chinensis (Turcz.) Baill.) // Биологические особенности лекарственных и ароматических растений и их роль в медицине: сборник научных трудов Международной научно-практической конференции. М., 2016. С. 391-394.

12. Добрина Ю.В., Мальцева А.А., Сорокина А.А., Сливкин А.И. Изучение химического и элементного состава листьев лимонника китайского, заготовленных в Воронежской области // Вестник ВГУ, Серия: Химия. Биология. Фармация. 2016. №1. С. 136-139.

13. Карташова Н.В., Самылина И.А., Стреляев А.В., Кузнецов Р.М. Изучение химического состава эфирного масла, полученного из лекарственного растительного сырья семян лимонника китайского (Schisandra chinensis Baill.) с помощью метода хромато-масс-спектрометрии // Разработка и регистрация лекарственных средств. 2017. №4 (21). C. 206-210.

14. Chunhui Deng, Guoxin Song, Yaoming Hu, Xiangmin Zhang. Analysis of the Volatile Constituents of Schisandra chinensis (Turz.) Bail by Gas Chromatography-Mass Spectrometry, Using Headspace Solid-Phase Microextraction // Chromatographia. 2003. Vol. 58. N5/6. Pp. 289-294.

15. Пономарева Е.И., Молохова Е.И., Холов А.К. Применение эфирных масел в фармации // Современные проблемы науки и образования. 2015. №4. URL: http://www.science-education.ru/21156.

16. Лебедев А.А. Лимонник. Ташкент, 1971. 114 с.

17. Литвинова Т. Великое лекарство китайских императоров от 1000 болезней. Лимонник: как лечиться и как выращивать. М., 2012. 190 с. 
18. Jeong J.W., Kim J.W., Ku S.K., Kim S.G., Kim K.Y., Kim G.Y., Hwang H.J., Kim B.W., Chung H.Y., Kim C.M., Choi Y.H. Essential oils purified from Schisandrae semen inhibits tumor necrosis factor- $\alpha$-induced matrix metalloproteinase- 9 activation and migration of human aortic smooth muscle cells // BMC Complement Altern Med. 2015. Vol. 15. Pp. 7-22.

19. Морозов Ю.А., Макиева М.С., Морозова Е.В. Изучение элементного состава и числовых показателей надземных и подземных органов лимонника китайского // Современные проблемы науки и образования. 2015 . №4. URL: http://www.science-education.ru/21015.

20. Раджабов Г.К., Алиев А.М., Вагабова Ф.А., Мусаев А.М. Компонентный состав эфирного масла Satureja subdentata Boiss. в природной и интродукционных популяциях из флоры Дагестана // Химия растительного сырья. 2017. №1. С. 65-70. DOI: 10.14258/jсprm.2017011390.

21. Королюк Е.А., Ткачев А.В. Химический состав эфирного масла двух видов полыни: Artemisia frigida и Artemisia argyrophylla // Химия растительного сырья. 2009. №4. С. 63-72.

22. Ткачев А.В. Исследование летучих веществ растений. Новосибирск, 2008. 969 с.

Поступила в редакичию 23 апреля 2018 г.

После переработки 26 сентября 2018 г.

Принята к публикации 2 октября 2018 г.

Для цитирования: Морозов Ю.А., Зилфикаров И.Н., Морозова Е.В., Алиев А.М., Ибрагимов Т.А. Сравнительный анализ эфирного масла растительного сырья лимонника китайского: листьев, деревянистых стеблей, корневищ с корнями // Химия растительного сырья. 2019. №1. С. 173-180. DOI: 10.14258/jcprm.2019013912.

Morozov Yu.A..$^{{ }^{*}}$, Zilfikarov I.N. ${ }^{2}$, Morozova E.V. ${ }^{1}$, Aliev A.M. ${ }^{3}$, Ibragimov T.A. ${ }^{4}$ COMPARATIVE ANALYSIS OF ESSENTIAL OIL THE VEGETABLE RAW MATERIAL SCHISANDRA CHINENSIS: LEAVES, WOODY STEMS, RHIZOMES WITH ROOTS

${ }^{1}$ North Ossetian State University. K.L. Khetagurov, ul. Vatutina, 44-46, Vladikavkaz, 362025 (Russia), e-mail:moroz52@yandex.ru

2 All-Russian Research Institute of Medicinal and Aromatic Plants, ul. Grina, 7/1, Moscow, 117216 (Russia)

${ }^{3}$ Institute of Physics. H.I. Amirkhanova Dagestan Scientific Center of the Russian Academy of Sciences, ul. Yaragskogo, 94, Makhachkala, 367003 (Russia)

${ }^{4}$ Dagestan State University, ul. Batyraya, 4, Makhachkala, 367000 (Russia)

This paper presents the results of an experimental study of the component composition of essential oil samples obtained from various vegetable raw materials of Schisandra chinensis (Schisandra chinensis (Turcz.) Baill.): branches (woody stems), rhizomes with roots and leaves. The extraction of essential oils was carried out by distillation with water vapor followed by extraction from the distillate with ethoxyethane. The largest yield of essential oil in terms of completely dry raw material is registered from rhizomes with roots $-0.99 \%$; the yield from leaves and branches was approximately the same: $0.51 \%$ and $0.52 \%$, respectively. A comparative analysis of the component composition of the obtained essential oils was carried out using the gas chromatography / mass spectrometry method. In the essential oil of the leaves 29 detected compounds (identified by 21 connection; dominant components: Cyclohexylmethyl ether sulphurous acid, $(+)$-trans-nerolidol, $\delta$-cadinene, Tridec- $(2 \mathrm{E})$-EN1-ol), woody stems 80 connections (identified 65 compounds; dominant components: ß-pinene, Camphene, Bornylacetate, (+)trans-nerolidol, p-tsimen, Tridecan-2-it, $\delta$-cadinene), rhizomes with roots 78 of the compounds (60 compounds identified; dominant components: $\delta$-cadinene, Bornylacetate, $\beta$-pinene, Camphene, Nerolidol-(E), Tridecan-2-it, $\gamma$-cadinene, Borneol).

For each sample of the studied essential oils selectivity and marker substances were established.

Keywords: Schisandra chinensis, essential oil, gas chromatography / mass spectrometry.

\footnotetext{
${ }^{*}$ Corresponding author.
} 


\section{References}

1. Oshkina Ye.V., Kolesnikova R.D., Vyvodtsev N.V., Tagil'tsev Yu.G. Izvestiya VUZov. Lesnoy zhurnal, 2014, no. 5, pp. 35-41. (in Russ.).

2. Mal'tseva A.A., Tamilina I.A., Nedosekova M.A., Trineyeva O.V., Slivkin A.I., Chistyakova A.S. Vestnik VGU, Seriya: Khimiya. Biologiya. Farmatsiya, 2015, no. 1, pp. 147-151. (in Russ.).

3. Karlina M.V, Kosman V.M., Pozharitskaya O.N., Shikov A.N., Makarov V.G. Razrabotka i registratsiya lekarstvennykh sredstv, 2014, no. 1, pp. 34-39. (in Russ.).

4. Torikov V.Ye., Meshkov I.I. Vestnik Bryanskoy GSKhA, 2016, no. 4 (56), pp. 50-54. (in Russ.).

5. Kosman V.M., Karlina M.V., Pozharitskaya O.N., Shikov A.N., Makarov V.G., Vorob'yeva V.V., Lapkina G.Ya. Obzory po klinicheskoy farmakologii i lekarstvennoy terapii, 2015, vol. 13, no. 4, pp. 3-21. (in Russ.).

6. Satdarova F.Sh., Kurkin V.A. Khimiya rastitel'nogo syr'ya, 2008, no. 3, pp. 59-63. (in Russ.).

7. Suprunov N.I., Gorovoy P.G., Pankov Yu.A. Efirnomaslichnyye rasteniya Dal'nego Vostoka. [Essential oil plants of the Far East]. Novosibirsk, 1972, 188 p. (in Russ.).

8. Zapatyl'ko F.T. Materialy $k$ izucheniyu zhen'shenya i limonnika: sbornik nauchnykh trudov. [Materials for the study of ginseng and lemongrass: a collection of scientific papers]. Moscow; Leningrad, 1955, vol. 2, pp. 97-99. (in Russ.).

9. Krotova I.V., Yefremov A.A. Khimiya rastitel'nogo syr'ya, 1999, no. 4, pp. 131-133. (in Russ.).

10. Krotova I.V., Yefremov A.A. Khimiya rastitel'nogo syr'ya, 2002, no. 3, pp. 29-33. (in Russ.).

11. Kolesnikova R.D., Tagil'tsev Yu.G. Biologicheskiye osobennosti lekarstvennykh i aromaticheskikh rasteniy $i$ ikh rol'v meditsine: sbornik nauchnykh trudov Mezhdunarodnoy nauchno-prakticheskoy konferentsii. [Biological features of medicinal and aromatic plants and their role in medicine: a collection of scientific papers of the International Scientific and Practical Conference]. Moscow, 2016, pp. 391-394. (in Russ.).

12. Dobrina Yu.V., Mal'tseva A.A., Sorokina A.A., Slivkin A.I. Vestnik VGU, Seriya: Khimiya. Biologiya. Farmatsiya, 2016, no. 1, pp. 136-139. (in Russ.).

13. Kartashova N.V., Samylina I.A., Strelyayev A.V., Kuznetsov R.M. Razrabotka i registratsiya lekarstvennykh sredstv, 2017, no. 4 (21), pp. 206-210. (in Russ.).

14. Chunhui Deng, Guoxin Song, Yaoming Hu, Xiangmin Zhang. Chromatographia, 2003, vol. 58, no. 5/6, pp. $289-294$.

15. Ponomareva Ye.I., Molokhova Ye.I., Kholov A.K. Sovremennyye problemy nauki i obrazovaniya, 2015, no. 4, URL: http://www.science-education.ru/21156. (in Russ.).

16. Lebedev A.A. Limonnik. [Lemongrass]. Tashkent, 1971, 114 p. (in Russ.).

17. Litvinova T. Velikoye lekarstvo kitayskikh imperatorov ot 1000 bolezney. Limonnik: kak lechit'sya i kak vyrashchivat'. [The Great Medicine of the Chinese Emperors for 1000 Diseases. Lemongrass: how to be treated and how to grow]. Moscow, 2012, 190 p. (in Russ.).

18. Jeong J.W., Kim J.W., Ku S.K., Kim S.G., Kim K.Y., Kim G.Y., Hwang H.J., Kim B.W., Chung H.Y., Kim C.M., Choi Y.H. BMC Complement Altern Med., 2015, vol. 15, pp. 7-22.

19. Morozov Yu.A., Makiyeva M.S., Morozova Ye.V. Sovremennyye problemy nauki i obrazovaniya, 2015, no. 4, URL: http://www.science-education.ru/21015. (in Russ.).

20. Radzhabov G.K., Aliyev A.M., Vagabova F.A., Musayev A.M. Khimiya rastitel'nogo syr'ya, 2017, no. 1, pp. 65-70, DOI: $10.14258 /$ jcprm.2017011390. (in Russ.).

21. Korolyuk Ye.A., Tkachev A.V. Khimiya rastitel'nogo syr'ya, 2009, no. 4, pp. 63-72. (in Russ.).

22. Tkachev A.V. Issledovaniye letuchikh veshchestv rasteniy. [Research on plant volatiles]. Novosibirsk, $2008 \mathrm{p} 969$ p. (in Russ.).

Received April 23, 2018

Revised September 26, 2018

Accepted October 2, 2018

For citing: Morozov Yu.A., Zilfikarov I.N., Morozova E.V., Aliev A.M., Ibragimov T.A. Khimiya Rastitel'nogo Syr'ya, 2019, no. 1, pp. 173-180. (in Russ.). DOI: 10.14258/jcprm.2019013912. 